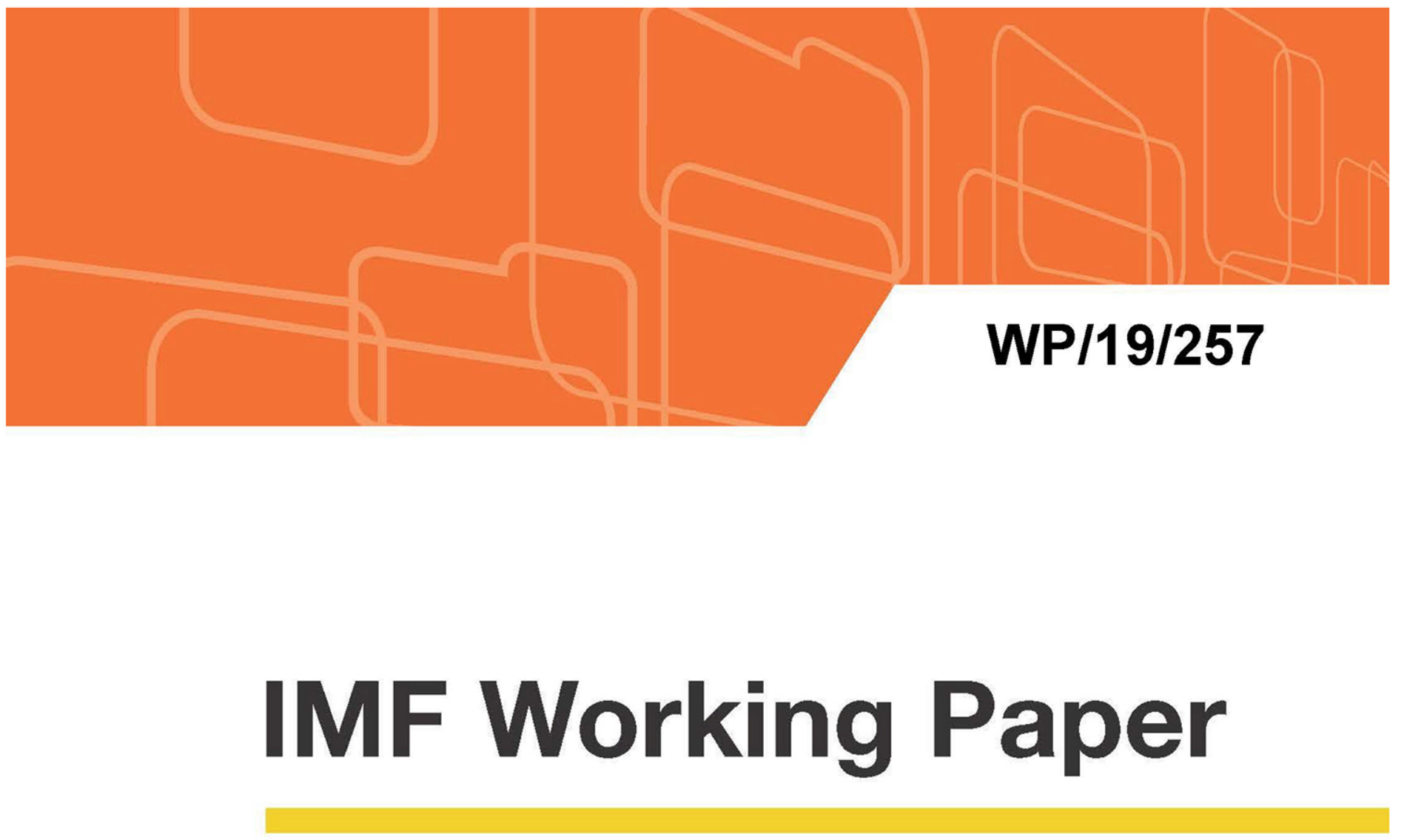

\title{
Informality and Aggregate Productivity: The Case of Mexico
}

\author{
by Jorge Alvarez and Cian Ruane
}

IMF Working Papers describe research in progress by the author(s) and are published to elicit comments and to encourage debate. The views expressed in IMF Working Papers are those of the author(s) and do not necessarily represent the views of the IMF, its Executive Board, or IMF management. 


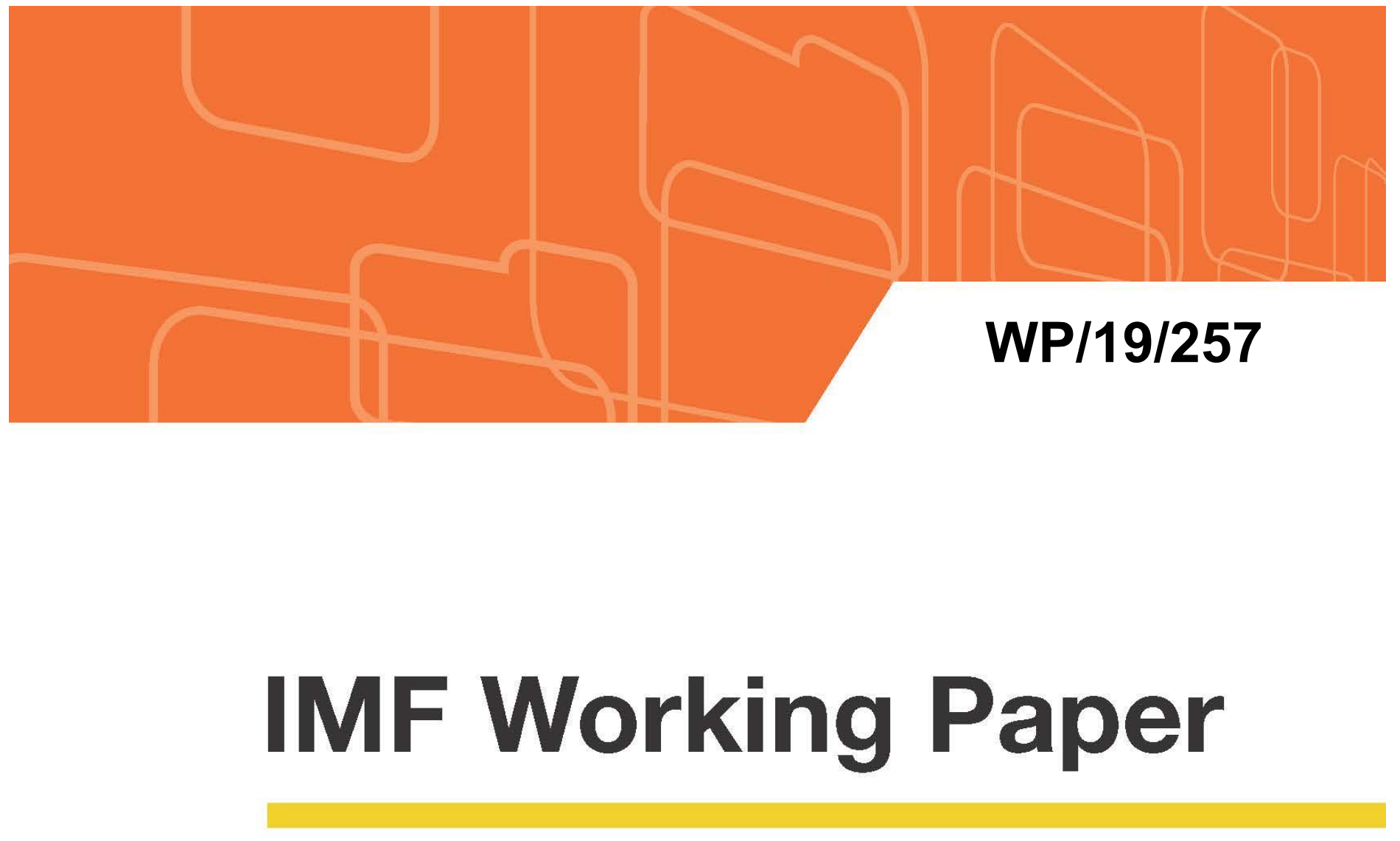

\section{Informality and Aggregate Productivity: The Case of Mexico}

by Jorge Alvarez and Cian Ruane

IMF Working Papers describe research in progress by the author(s) and are published to elicit comments and to encourage debate. The views expressed in IMF Working Papers are those of the author(s) and do not necessarily represent the views of the IMF, its Executive Board, or IMF management.

I N T E R N A T I O N A L M O N E T A R Y F U N D 


\title{
IMF Working Paper
}

\author{
WHD and RES
}

\section{Informality and Aggregate Productivity: The Case of Mexico \\ Prepared by Jorge Alvarez and Cian Ruane ${ }^{1}$}

Authorized for distribution by Costas Christou

November 2019

\section{IMF Working Papers describe research in progress by the author(s) and are published to elicit comments and to encourage debate. The views expressed in IMF Working Papers are those of the author(s) and do not necessarily represent the views of the IMF, its Executive Board, or IMF management.}

\begin{abstract}
We assess the aggregate productivity impact of distortions arising from labor regulations in Mexico and how they interact with informality. Using employment surveys and a firm-level economic census, we document a number of novel features about informal firms in Mexico. We then construct and estimate a model of heterogeneous firms and endogenous informality to study the micro and macro impacts from various policy reforms. Some reforms may have large impacts on informal employment but small impacts on aggregate productivity.
\end{abstract}

JEL Classification Numbers: D22, E26, H26, J46, O14, O17

Keywords: Informality, Misallocation, Productivity, Growth, Mexico.

Author’s E-Mail Address: jalvarez@,imf.org; cruane@imf.org

\footnotetext{
${ }^{1}$ We are grateful to Natalia Volkow and the Mexican Statistical Institute (INEGI) staff for their collaboration with this project. We also appreciate the valuable comments and input from Julia Bersch, Marcela Eslava, Cristina Fernandez, Pete Klenow, Santiago Levy, Nan Li, Chris Papageorgiou, Diego Restuccia, Christian Saborowski, Jessica Torres, Gabriel Ulyssea, and Alejandro Werner at various stages of this project. The views in this study are the sole responsibility of the authors and do not represent the views of the IMF or INEGI.
} 


\section{Introduction}

Many developing economies are characterized by large informal sectors which are comprised of unproductive firms and which provide low-paying jobs (La Porta \& Schleifer, 2014). Two arguments are frequently put forward for why informality might be a contributing factor to aggregate income differences across countries. Firstly, informality may induce a misallocation of capital and labor towards less productive firms thereby lowering aggregate productivity (Hsieh \& Klenow, 2009). Secondly, informality impedes the proper collection of taxes necessary for a functioning government. However, informality may provide some flexibility for firms to evade burdensome regulations. Informal firms are also the largest source of employment for workers in developing countries. The welfare and aggregate productivity effects of policies which eradicate the informal sector are therefore ambiguous. Any formalization strategy is thus faced with two unresolved questions: what are the most salient drivers of informality and what would be the distributional and aggregate effects from addressing them?

We explore these questions using a structural model to interpret important facts about informality in Mexico which we construct from a rich set of employment surveys and firm-level micro-datasets. In the first part of the paper we document the prevalence of informal firms in Mexico, the high share of informal employment that exists within formal firms, and the wage, size, and productivity structure of the formal and informal sectors. The data reveals the complex nature of informality in Mexico, where large heterogeneity in productivity, wages, and sizes exists among both among formal and informal firms across multiple economic sectors. ${ }^{1}$ Peculiarly, there are both large and small informal firms in Mexico, and formal firms often employ large shares of informal non-salaried workers in their ranks. This is at least partially due to a set of labor regulations

\footnotetext{
${ }^{1}$ Throughout the paper we follow Levy (2018) and define informality in terms of firms' and workers' participation in the social security system.
} 
-including payroll taxation and features of co-existing social security systemsthat incentivize numerous informal contractual arrangements across different firm types. These distortive labor regulations have been viewed as a significant driver of Mexico's large informal sector, large resource misallocation ${ }^{2}$, and overall low aggregate productivity (Levy, 2018). ${ }^{3}$

In the second part of the paper we construct and estimate a model of heterogeneous firms and endogenous informality to assess the importance of these distortions and their micro and aggregate economic effects. The framework is close to that of Ulyssea (2018), where there are two important margins of informality. On the one hand, entrepreneurs can choose to set up formal or informal firms, which require distinct entry and registration costs and are subject to different sets of distortions when operating. This is the extensive margin of informality. On the other hand, formal firms can chose to hire formal or informal workers as part of their operations. The fundamental trade-off is that of paying for mandatory social security contributions and taxes required for formal workers or risk the probability of sanctions or efficiency losses from hiring informal workers. This is the intensive margin of informality. Unlike Ulyssea (2018), firms not only face different entry and homogeneous labor costs according to their formality status but also face idiosyncratic distortions whose distributions are different in the formal and informal sectors. ${ }^{4}$ In the model, heterogeneous entrepreneurs optimize over both margins according their own characteristics, the regulatory environment, and the idiosyncratic distortions present in their sector.

\footnotetext{
${ }^{2}$ As documented by Hsieh and Klenow (2014).

${ }^{3}$ The literature has emphasized the role of taxation, social security contributions, noncontributory benefits in discouraging formality, the limited value of contributory benefits, and the effect of size-specific tax regimes such as Repeco and enforcement policies in inducing labor and capital misallocation towards the informal sector. Levy (2018) provides a relevant summary and expanded discussion of this research and concludes that formalization frictions lead to significant aggregate TFP losses in Mexico.

${ }^{4}$ These are informed by production and input data from the Mexican Economic Census for both formal and informal firms.
} 
This framework is able to rationalize and reconcile three views on informality highlighted by the literature. ${ }^{5}$ According to the first view, informal entrepreneurs are potentially productive and would like to operate in the formal sector but are unable to do so because of high formalization barriers. ${ }^{6}$ The second view of informality is one of parasitic entrepreneurs who are productive enough to operate in the formal sector but choose not to in order to avoid taxes and regulations. Finally, the third view is that the informal sector is populated by low productivity entrepreneurs who could never formalize and would therefore disappear if informality were to be eradicated. Like Ulyssea (2018), firms conforming to these three views co-exist as an equilibrium outcome in our framework. Moreover, each type of firm reacts differently to the policy experiments studied.

Our results suggest that distortions are large in Mexico. In the model, these distortions induce substantial misallocation in both the formal and informal sectors, with greater misallocation in the latter. We find that removing formal sector regulatory labor distortions from taxation and social security does not seem to have a large impact on the number of formal firms, nor on misallocation or aggregate productivity. Removing labor distortions does, however, substantially increase the share of employment that is formal in the economy. Intuitively, reducing labor distortions makes formal workers relatively cheaper, and primarily affects the intensive margin of informality. Effects on the extensive margin from these distortions are less prominent, since only marginal firms at the low end of the firm-size spectrum are affected. In contrast, we find that reducing formal sector entry costs leads to a large increase in the number of formal firms, and simultaneous substantial decrease in informal employment and increase in aggregate productivity. ${ }^{7}$ Thus, reducing formalization entry costs

\footnotetext{
${ }^{5}$ See La Porta and Shleifer (2014) and Ulyssea (2018) for a discussion of these views.

${ }^{6}$ In Latin America, this view was most prominently articulated by De Soto (1989).

${ }^{7}$ Entry costs in our model capture the myriad of financial and non-financial upfront costs
} 
and reducing distortive labor regulation both boost formality through different margins, therefore having distinct aggregate and distributional impacts. A key takeaway from this analysis is that informal employment and aggregate productivity can respond very differently to reforms. In the case of Mexico, we find that addressing high entry barriers to formalization and idiosyncratic distortions beyond labor regulation (or heterogeneous enforcement of labor regulation) could be an important source of productivity gains.

Our results complement recent modeling approaches and an extensive empirical literature studying the effects of regulation on informality and aggregate outcomes. Ulyssea (2018) apply a framework similar to ours for Brazil without idiosyncratic distortions. Ulyssea and Ponczek (2019) and Dix-Carneiro et al. (2018) develop a similar framework linking informality distortions to trade. Meghir, Narita and Robin (2015) develop a wage-posting framework and find positive effects from tightening enforcement. Charlot, Malherbet, and Terra (2015) propose a model of formal and informal firms facing product and labor market imperfections and D'Erasmo and Boedo (2012) develop a framework with capital market frictions. Close to our emphasis on the intensive margin of informality, Bertrand, Hsieh, and Tsivanidis (2015) use a model of firm growth and firing costs to study the effect of informal labor contracts on TFP growth in India. For the case of Mexico, Leal (2014) proposes a dynamic model to study the link between tax collection, informality and productivity. In terms of empirical studies, Bruhn (2011, 2013) and Kaplan, Piedra and Sira (2015) find limited positive effects on formal business registration from speeding-up business startups, and Anton, Hernandez, and Levy (2013) and Bosch, Cobacho, and Pags (2014) highlight the effects of Mexican social security systems on informal employment. Other recent studies focusing on the impact of tax and entry cost regulation on informality and aggregate outcomes include Rocha, that entrepreneurs need to pay to enter the formal sector. 
Ulyssea, and Rachter (2018), Monteiro and Assunao (2012), Fajnzylber, Maloney, and Montes-Rojas (2011), Almeida and Carneiro (2012), and De Andrade, Bruhn, and McKenzie (2014), among others.

The rest of paper proceeds as follows. Section 2 documents a number of empirical facts about informality in Mexico from the worker and firm perspectives. Section 3 summarizes the regulatory environment. Section 4 describes the model's mechanics. Section 5 outlines the estimation of the model and Section 6 shows the results of policy counterfactual exercises. Section 7 concludes.

\section{Stylized facts about informality in Mexico}

This section describes the datasets and definitions of formality used, documents informality levels and trends in Mexico, and decomposes the distribution of productivity and wages across workers and firms in the formal and informal sectors.

\subsection{Data description and definitions of informality}

We use two main datasets to document informality in Mexico from both the worker and firm perspectives. The first is the National Employment Survey (ENOE). This nationally representative survey includes both formal and informal workers and records both demographic characteristics as well as information on the worker's contractual status and employer type. Worker demographic characteristics include gender, age, educational attainment, and municipality. In addition, the survey also reports the employment status of the worker, labor earnings, hours worked, social security benefits received, and whether the worker is salaried or non-salaried.

Employer characteristics include sector, firm size (as reported by the employee), and information related to the formality status of the firm. Given 
the structure of informality in Mexico, this study differentiates between formal/informal firms and formal/informal workers. An important feature of Mexican informality is that firms classified as formal employ a substantial share of workers in non-salaried informal contractual relationships. The definition of informal firms in this context includes subsistence agriculture, domestic work, and firms classified as informal by the Mexican National Institute of Statistics and Geography (INEGI) based on reported name, family ownership, and accounting practices. All other firms are classified as formal. From the worker's side, following criteria from INEGI, the definition of informal workers includes those at non-agricultural informal firms, self-employed agricultural workers, unpaid workers, non-salaried workers (at both formal and informal firms), and workers without access to social security health services in both formal and informal firms. Workers in non-salaried contractual relationships, including those at formal firms, are therefore included in the informal worker category. None of the workers under this definition have access to Mexican Social Security Institute (IMSS). All other workers are defined as formal.

A key feature of the ENOE is its rotating panel structure, where each household is followed for five consecutive quarters. This allows for the documentation of transitions between formal and informal worker status and transitions into and out of formal firms. It also allows the estimation of formal-informal wage gaps accounting for worker fixed effects. The ENOE samples over one hundred thousand households per quarter, who are continuously replaced to guarantee national and regional representativity. This study focuses on workers aged 14 to 65 who report being employed.

The second dataset used is an establishment-level census data from the Mexican Economic Census. ${ }^{8}$ INEGI compiles the data set every five years, for which we use the waves from 1998, 2003, 2008, and 2013. This includes millions obser-

\footnotetext{
${ }^{8}$ See Levy (2018) and INEGI (2013) for a more detailed description of the data.
} 
vations covering the universe of non-agricultural formal and informal Mexican firms that have fixed establishment in urban areas across all industries. The census covers a vector of firm characteristics including location, revenues, value added, wage bill and other labor costs, social security contributions, and number of workers. Since firm characteristics reported in the ENOE and Mexican Economic Census are different, we cannot use the same definition of formality. In this study, we classify firms that make any social security contribution as formal when reporting moments from census data. For the model estimation described in section 5 , this is the definition of informality used.

\subsection{Informality levels and trends in Mexico}

Labor market informality in Mexico has remained stubbornly high over the last decade. Although the growth of formal jobs has outpaced the growth of overall employment in the Mexican economy in recent years, the share of formal employment has only slightly increased from 42 percent in 2005 to 44 percent by 2019. Mexico's current level of employment informality is slightly above the Latin American average (Figure 1), and remains well-above levels observed in advanced economies.

As mentioned, an important feature of Mexican informality is that a substantial share of workers have informal contractual relationships at formal firms. Under the definition of formality constructed from the ENOE, while 44 percent of workers are fully formal, around 22 percent of workers work at formal firms without reporting access to full benefits. That is, there is a significant number of informal workers at formal firms under a variety of contractual relationships, from unpaid work to non-salaried contracts, without access to contributory social security programs. Although the composition of formality has changed over time in Mexico, the large role of non-formal contractual relationships at formal 
Table 1: Worker CHARACTERISTiCs By Informality Status in Mexico

\begin{tabular}{lcccccc} 
& \multicolumn{9}{c}{$\begin{array}{c}\text { Informal } \\
\text { Formal }\end{array}$} & \multicolumn{2}{c}{ at formal firms } & \multicolumn{2}{c}{ Informal } \\
\hline & Avg. & S.d. & Avg. & S.d. & Avg. & S.d. \\
\hline & & & & & & \\
Percent of employed & 41.94 & & 21.60 & & 36.46 & \\
& & & & & & \\
Education & 3.23 & 1.45 & 2.26 & 1.41 & 1.93 & 1.18 \\
Ageducation refers to.. & 37.82 & 11.43 & 34.6 & 13.23 & 37.95 & 13.47 \\
Log(Wage) & 3.4 & 0.68 & 2.82 & 0.77 & 3.02 & 0.74 \\
\hline
\end{tabular}

Sources: ENOE 2013; and staff calculations.

firms in Mexico has remained significant throughout the period of study.

Figure 1: WoRKER INFORMALITY IN MEXICO Vs OTHER ECONOMIES

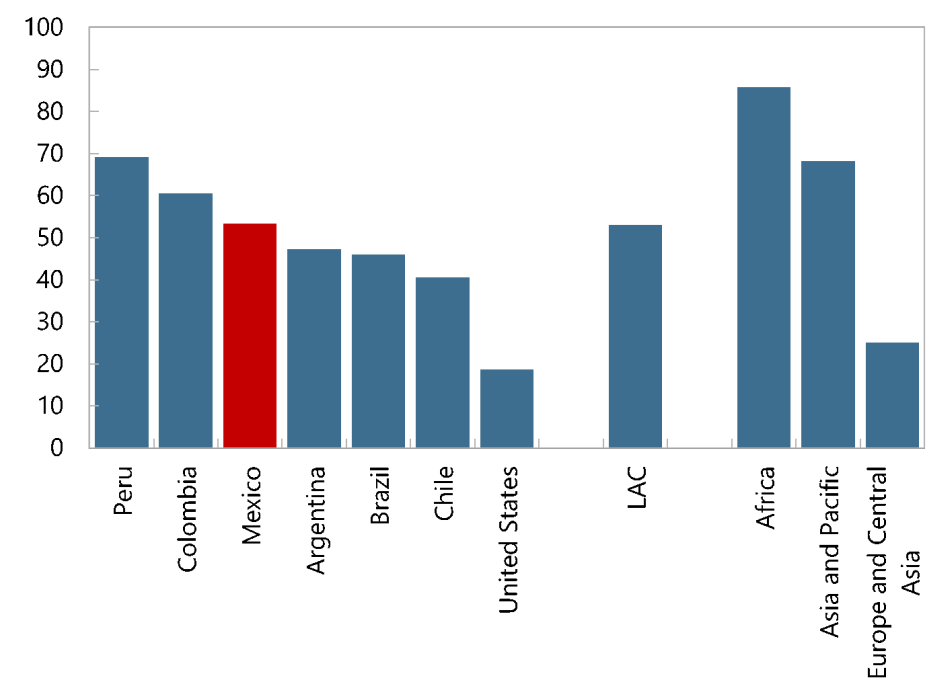

Sources: ENOE and ILO 2018. 


\subsection{The role of worker characteristics and formal-informal transitions}

Informal workers earn less and are less educated than formal ones (Table 1). ${ }^{9}$ Nevertheless, informality is not an exclusive feature of the poorest and least educated workers. Figure 2 shows the prevalence of informality by education level, which has been relatively stable in Mexico. Although informality rates are higher among workers without a high school degree, there is still a significant share of educated workers who work at informal firms (21 percent) or who have informal contractual relationships at formal firms (17 percent). Figure 3 shows the density of log wages for both sectors before and after controlling for worker demographics including age, education, and gender. There is a substantial overlap in the distribution of wages in both sectors, with the variance of log wages being 0.74 among formal workers and 0.65 among informal ones. This overlap is present even after accounting for differences in observable demographics (including age and education). Informality is thus prevalent, not only across different education groups, but also both among both low and high paying jobs. The prevalence of informality across sectors, income strata, and both formal and informal firms paints a picture of a market duality that permeates all of the Mexican economy.

\footnotetext{
${ }^{9}$ ENOE 2013 data shown to simplify comparability with the latest Economic Census.
} 
Figure 2: Distribution By EdUCATion LeVel

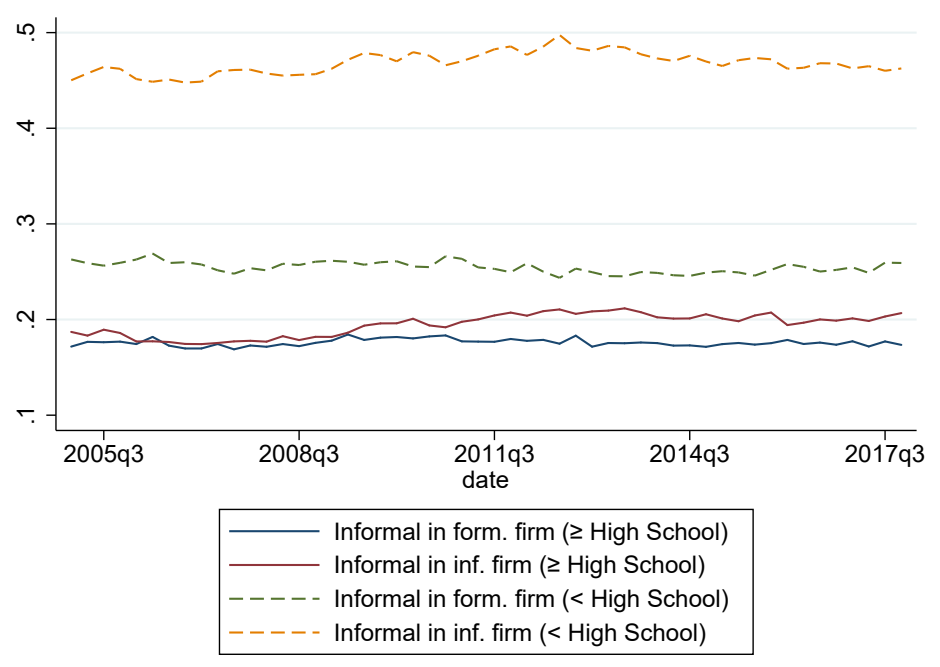

Figure 3: Distribution OF WAGES

(a) Without controls

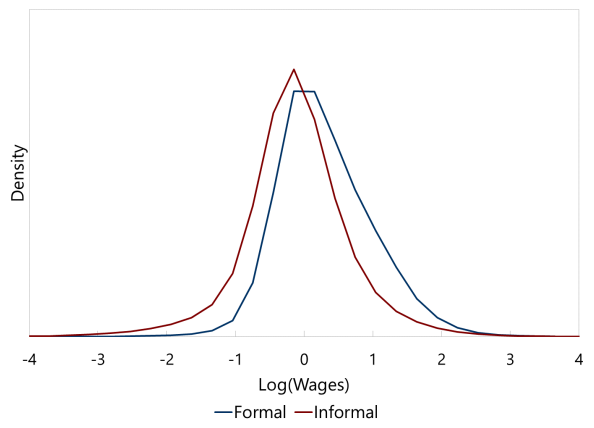

(b) After controlling for observables

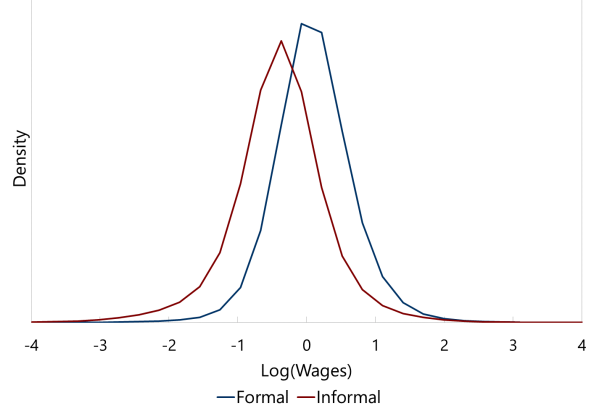

Sources: ENOE; and staff calculations.

Table 2 shows the estimated wage gap between the formal and informal sectors controlling for age, education, time, economic sector, and worker fixed effects. Relative to informal workers outside of formal firms, formal workers earn a premium of $41 \log$ points in the raw data and of 47 log points once sec- 
toral differences are accounted for. Taking specifications with sector controls as a baseline, controlling for differences in education and age between workers reduce this gap from 47 to 23 log points. This implies that differences in education and education account for over half of this overall gap in wages. Crucially, informal workers at formal firms do not get a premium, as they tend to report wages that are lower than informal workers at informal firms on average. A large share of this discount is explained by their younger age and the sectors that they work for. Controlling for these differences reduces the gap between informal workers at formal and informal firms from -21 to -3 log points. Accounting for both observable and unobservable characteristics, the formality premium is significantly reduced. Controlling for individual fixed effects lower the formality premium from 23 to $4 \log$ points, relative to the specification with only observable demographics. Altogether, the results imply that differences in worker composition, as controlled by observable and fixed unobservable characteristics, account for 92 percent of the overall wage gap. ${ }^{10}$ This low residual wage gaps suggest a limited role of firms in determining average wage differences between formal and informal firms. Transitions into formal firms involve only a modest wage premium.

Furthermore, workers frequently move between formality and informality in Mexico as shown in Figure 4. Around four percent of workers move from formality to informality in a given quarter, and similar proportion move in the opposite direction. When dissecting transitions to informality between workers moving to informal firms and those moving to informal positions (mostly non-

\footnotetext{
${ }^{10}$ Result of comparing columns (2) and (6) in Table 2. It is important, however, to qualify this statement as the latter wage premiums are only estimated using workers who switch across sectors. These switchers do not form a representative sample of the population; therefore, it might still be the case that gains from formalization are greater for workers who do not switch across sector. In addition, given that the panel structure of the dataset follows a worker for only five quarters, wage premiums are exclusively affected by short-term gains from transitioning across sectors. This implies that, although estimated short-term wage premiums are relatively small, long-term gains from formalization might still significant.
} 
Table 2: Formality Wage Premiums

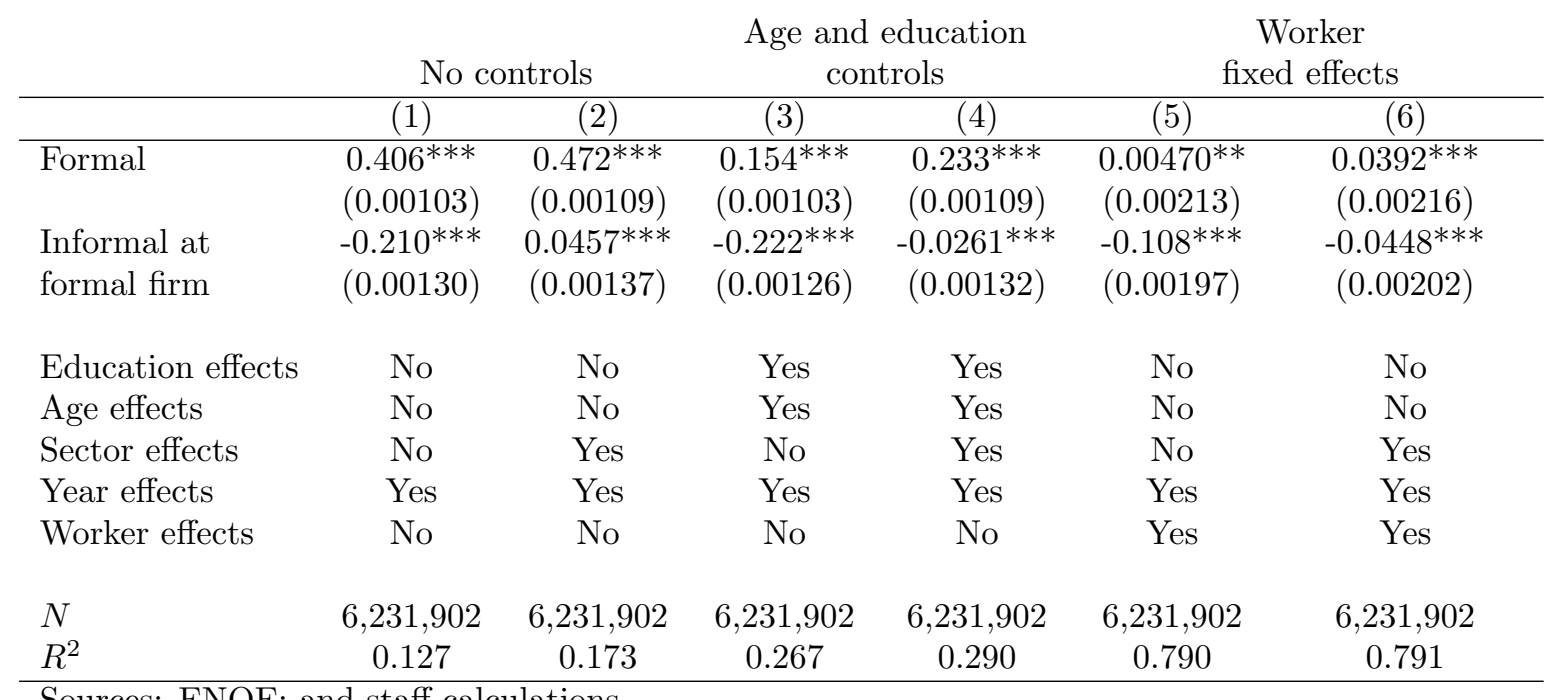

Note: Regressions with log(wage) as the dependent variable. Year, sector, education and age included as a vector of age and education dummies. Education categories are none, primary, secondary, high school, tertiary technical degree and $>$ college completed. Sectors are agriculture, construction, manufacturing, and services. Robust standard errors in parentheses $* * * \mathrm{p}<0.01$, ** $\mathrm{p}<0.05, * \mathrm{p}<0.1$. 
salaried) at formal firms, we see similar bidirectional flows. Moreover, the most common transitions are those between holding formal and informal jobs within formal firms.

Figure 4: WORKER FLOW PATTERNS IN AND OUT OF INFORMALITY IN MEXICO

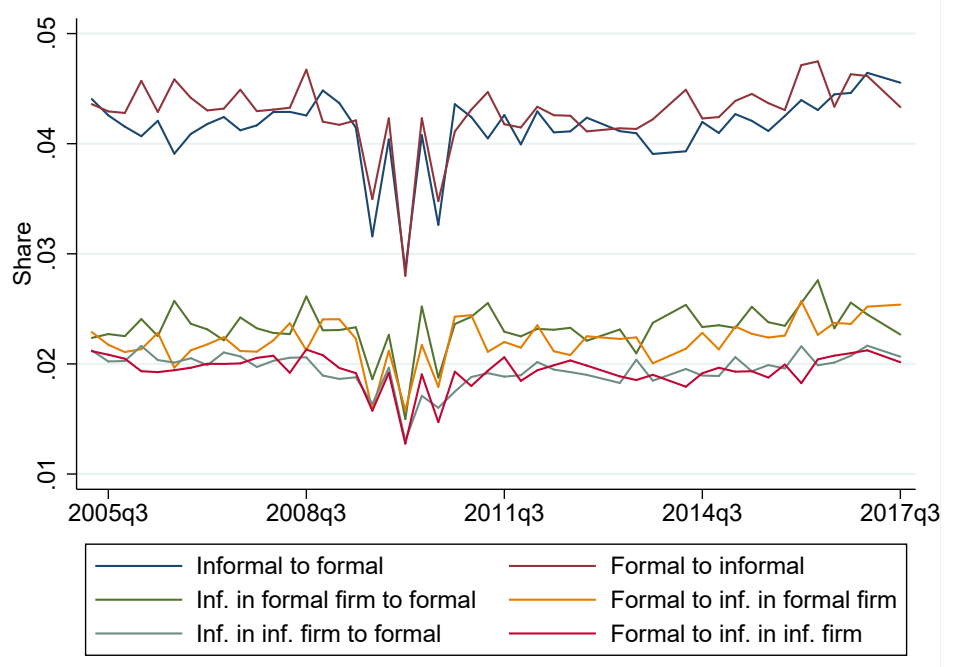

Sources: ENOE; and staff calculations.

Both the modest wage premiums from formality and the presence of bidirectional formality-informality flows suggest that differences in productivity and pay between the formal and informal sectors are not arising from frictions preventing the movement of workers from one sector to another. This motivates our view of Mexican market duality, to be formalized by the model, as the equilibrium of a system were workers can move freely between sectors and are paid, to a large extent, the marginal value product of their labor.

\subsection{The role of firm characteristics and hiring strategies}

We now focus on informality from the firm perspective using census data. There are over three hundred thousand formal firms and three million informal firms 
with reported employees in the 2013 Mexican Economic Census. The average formal firm is larger with 21.4 workers per establishment compared with 2.7 workers per establishment at informal firms. Moreover, formal firms are on average more productive - as documented by value added per worker- than informal firms as documented by Table 4 . The raw productivity gap between formal and informal firm is $141 \log$ points. This is reduced to $105 \log$ points after introducing sector fixed effects, $85 \log$ points after controlling for firm size, and $36 \log$ points after controlling for the share of workers hired formally. The results show that larger firms are more productive than smaller ones within both the formal and informal sectors and that the formality productivity premium is not entirely driven by economic sector composition. The results are similar when municipality fixed effects are included.

Beyond average productivity gaps, there is substantial dispersion in value added per worker within both the formal and informal sectors. More specifically, the 90 th-10th percentile ratio in value added per worker (in logs) is 3.7 in the informal sector and 2.6 in the formal sector. Mirroring the pattern documented for wages, Figure 5 shows that there is significant overlap in productivity between formal and informal firms. The figure also shows that the mass of informal unproductive firms (e.g. below median productivity) is much higher than formal unproductive ones while, at the same time, there are both very productive and very unproductive firms in both sectors. 
Table 3: Firm CHARACTERISTICS By INFORMALITy STATUS

\begin{tabular}{lcccccccc} 
& \multicolumn{2}{c}{1998} & \multicolumn{2}{c}{2003} & \multicolumn{2}{c}{2008} & \multicolumn{2}{c}{2013} \\
\hline & Inf. & For. & Inf. & For. & Inf. & For. & Inf. & For. \\
\hline & & & & & & & & \\
Share of firms & 0.82 & 0.18 & 0.87 & 0.13 & 0.89 & 0.11 & 0.89 & 0.11 \\
Share of labor & 0.32 & 0.68 & 0.41 & 0.59 & 0.48 & 0.52 & 0.49 & 0.51 \\
& & & & & & & & \\
Workers per firm & & & & & & & & \\
$\quad$ Mean & 2.0 & 19.2 & 2.5 & 23.8 & 3.1 & 26.4 & 2.7 & 23.8 \\
S.d. & 21.4 & 135.3 & 17.5 & 165.4 & 37.7 & 323.8 & 24.7 & 366.5 \\
90-10 ratio & 3.0 & 12.5 & 4.0 & 16.5 & 4.0 & 17.5 & 4.0 & 15.0 \\
& & & & & & & & \\
Share of salaried & & & & & & & & \\
$\quad$ Mean & 0.15 & 0.83 & 0.16 & 0.81 & 0.18 & 0.80 & 0.15 & 0.85 \\
S.d. & 0.32 & 0.24 & 0.32 & 0.22 & 0.32 & 0.23 & 0.32 & 0.21 \\
90-10 ratio & & 2.00 & & 2.00 & & 2.00 & & 2.00 \\
& & & & & & & & \\
V.A. per porker & & & & & & & & \\
$\quad$ Mean & 2.54 & 3.81 & 2.92 & 4.20 & 2.82 & 4.14 & 3.04 & 4.45 \\
S.d. & 1.20 & 1.02 & 1.26 & 0.98 & 1.36 & 1.13 & 1.37 & 1.02 \\
90-10 ratio & 3.13 & 2.54 & 3.38 & 2.46 & 3.61 & 2.83 & 3.65 & 2.54 \\
& & & & & & & & \\
Number of firms & 1.88 & 0.42 & 2.37 & 0.35 & 2.48 & 0.31 & 3.19 & 0.38 \\
\hline $\begin{array}{l}\text { Sources: Mexican Economic Census; and staff calculations. } \\
\text { Notes: V.A. refers to the log of value added per worker. Number of firms } \\
\text { in millions. }\end{array}$ & & & & & & & & \\
&
\end{tabular}


Table 4: Formality PRODUCTIVITy PREMIUMS

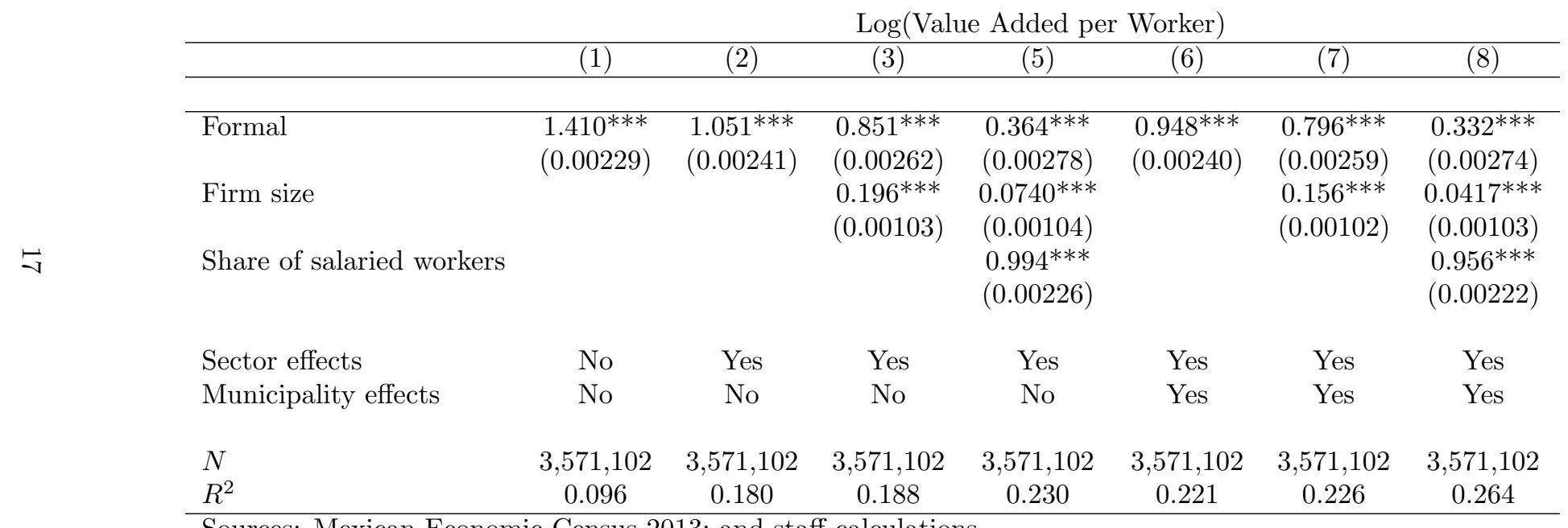

Sources: Mexican Economic Census 2013; and staff calculations.

Note: Four-digit sector codes used. Firms size control is the log of employed. 
Figure 5: Productivity DISPERSION OF FORMAL VS INFORMAL FIRMS

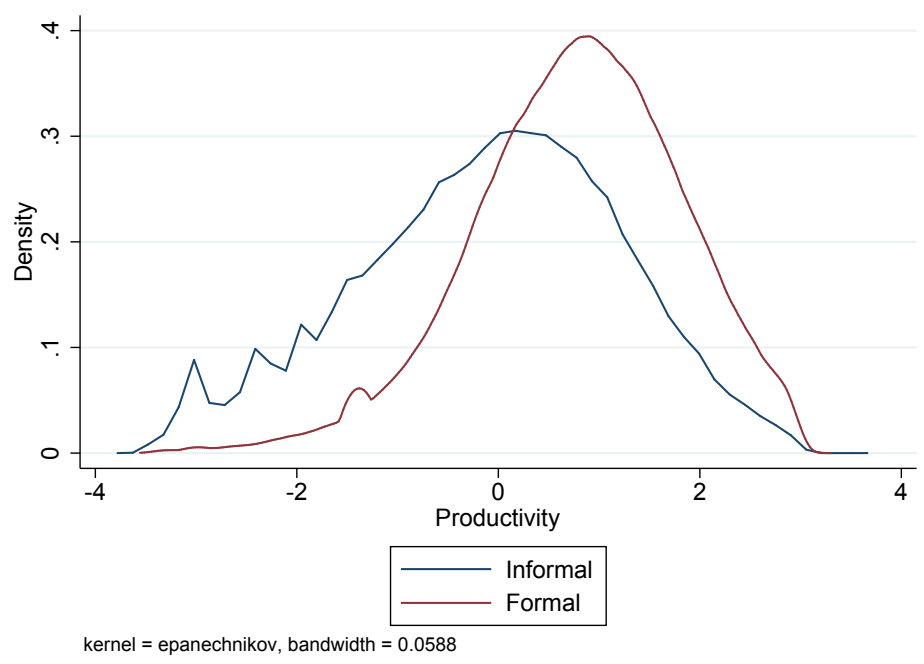

Sources: Mexican Economic Census 2013; and staff calculations.

Note: Dispersion of value added per worker conditional on sector controls.

In this paper, we focus on how distortions affecting the extensive (more informal firms) and intensive margins (more informal workers within formal firms) of informality can affect the observed productivity distributions and resulting aggregate productivity in the economy. Figure 6 shows how these two margins look in the 2013 Mexican Census. There are numerous informal firms across different sectors, firm sizes, and productivity categories in Mexico, with smaller firms exhibiting much greater informality prevalence. Looking at formal firms, there is also substantial heterogeneity in the intensive use of informal workers. While formal firms with 1-5 workers hire 19 percent of them in non-salaried informal contracts, this is only seven percent when looking at firms with $51+$ workers. Both the prevalence and systematic relationship between informality prevalence and size is partially the result of specific features of Mexican regulation. We describe this system next. 
Figure 6: Extensive vs Intensive Margin - Mexico 2013

(a) Extensive margin

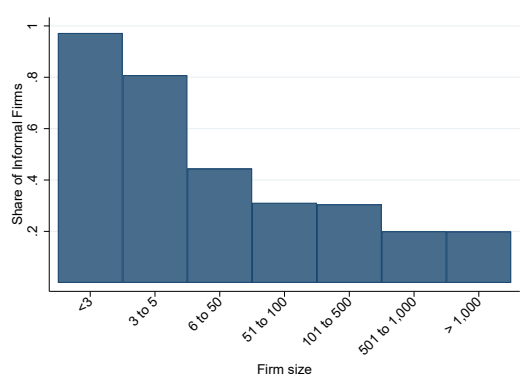

(b) Intensive margin (at formal firms)

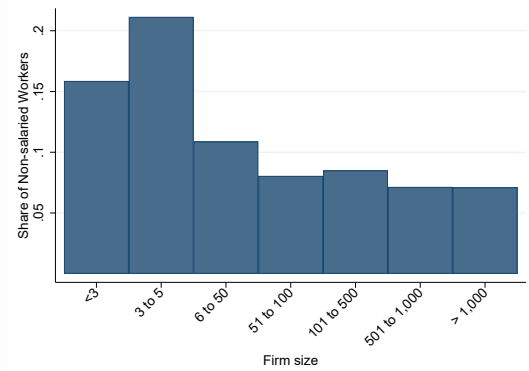

Sources: Mexican Economic Census 2013; and staff calculations.

\section{$3 \quad$ Regulatory drivers of informality}

The Mexican regulatory system features a number of incentives affecting the formalization decisions of firms and workers. On the one hand, there are several costs that a formal firm must pay when hiring a formal salaried worker. First, formal firms must enroll salaried workers in the social security registry (IMSS) and pay a contribution proportional to worker's wages in a scale that contains a regressive fixed cost component. Non-compliance is subject to monetary fines in the rage of 20-350 daily minimum wages per non-registered workers. ${ }^{11}$ These social insurance contributions can comprise around 30 percent of the wage and are only mandatory for fully formal salaried employees.

These contributions are not distortionary if they are fully compensated by equally valued benefits. Nonetheless, there is evidence of limited net benefits from IMSS membership, implying a net tax on formal salaried workers. On the one hand, there is a non-contributory social insurance system that is fully financed by the government where workers receive free benefits (including health and retirement) without making contributions. On the other hand, social secu-

\footnotetext{
${ }^{11}$ Bobba et al. (2017)
} 
rity benefits are bundled, only provide limited additional benefits to workers who already have an enrolled family member in the household, and have minimum contribution requirements. ${ }^{12}$ These features limit the overall net benefit from social security contributions. Levy (2018) estimates that considering benefits and costs of social security systems imply an implicit tax on salaried contracts of 12 percent.

Second, formal firms hiring salaried workers can be sued for unfair dismissals, implying a contingent liability for hiring formal salaried workers at formal firms. Labor lawsuits arising from this regulation often lead to long legal dispute processes that, in the past, led to an accumulation of payments owed by firms directly linked to the length of the dispute. Heckman and Pages (2004) estimate an implicit costs from severance pay regulations of around 3.2 percent of wages. ${ }^{13}$

Third, taxation policies favor non-salaried or informal employment. At the state level, state payroll taxes amounting to between 2 to 3 percent of wages apply only to salaried workers. At the federal level, federal income taxes do apply to all workers at formal firms but firms are only required to withhold income taxes for formal salaried ones. This leads to widespread evasion of the tax by non-salaried workers, who pay about one-fourth of the expected contributions based on aggregate estimates. ${ }^{14}$

Beyond barriers for the hiring of fully formal employees, entry costs and distortionary policies also disincentivize entrepreneurs from establishing formal firms. To establish a formal company, an entrepreneur needs to obtain authorization for the use of the company name, incorporate the company through a

\footnotetext{
${ }^{12}$ For instance, there is minimum requirement of ten contributing years to obtain retirement benefits through IMSS. A large share of workers do not obtain full retirement benefits as a result of this rule.

${ }^{13}$ The 2017 and 2019 labor reforms has limited these firing costs and has allowed for processes aimed at facilitating dispute resolution processes.

${ }^{14}$ Levy (2018) reports that taxes collections from salaried workers account for 2.5 percent of GDP while tax collections from non-salaried employment account for only 0.1 percent.
} 
notary, file incorporation with the Public Registry of Commerce, obtain a tax registry number with federal and local tax authorities, register at IMSS, notify the local government of the opening of a mercantile establishment, register with the National Business Information Registry and pay fees associated with these steps. ${ }^{15}$ In addition, there are standard features of regulatory systems in most countries such as overall taxation and minimum wages (which are relatively low in Mexico but are expected to double in the next five years), and also sector and size-specific taxation and regulatory enforcement regimes. Of these, the most prominent is the Small Contributor Regime (Repeco), which absorbs 93 percent of firms, 52 percent of labor, and 25 percent of capital of the economy (Levy, 2018). Finally, there are also imperfect persecution of tax evasion and regulatory violations, which tends to favor small informal firms whose probability of facing penalties is lower.

\section{A model of informality and misallocation}

In order to assess how regulatory and non-regulatory distortions interact with informality in Mexico, we build on the work of Ulyssea (2018) by modeling heterogeneous firms who choose to be formal or informal; the extensive margin of informality. In addition, formal firms choose how many formal and informal workers to hire; the intensive margin of informality. Firms face both regulatory and idiosyncratic barriers distorting their input and formality choices, leading to a misallocation of inputs across firms which lowers aggregate productivity. Following the evidence shown in the previous sections, we make the simplifying assumption that workers are homogeneous and are indifferent between being

\footnotetext{
${ }^{15}$ Doing Business (2019). Mexico ranks 94th out of 190 economies in costs and procedural burdens of starting a business. The cost of starting a business is estimated at 17 percent of income per capita.
} 
informal and formal. ${ }^{16}$ We now describe each of the model's components in detail.

\subsection{Heterogeneous firms}

There are two sectors in the economy: formal and informal. Firms in both sectors have access to the same technology and produce a homogeneous good (price normalized to one). The production function is given by $y_{i}=\theta_{i} l_{i}^{\alpha}$, where $\theta_{i}$ is the firm's idiosyncratic productivity, $l_{i}$ is the labor used in production, and $\alpha<1$ is the rate of decreasing returns to scale.

Informal firms face two types of distortions: 1) regulatory distortions which are faced by all informal firms and increase in firm size: $r^{I}\left(l_{i}\right)$, and 2) idiosyncratic distortions: $\tau_{i}^{I}$. The former are motivated by the regulatory barriers documented in the previous section. The latter capture any other idiosyncratic factor that would drive a wedge between a firm's marginal revenue and its marginal cost. ${ }^{17}$ Informal firms face overhead costs of operation $c^{I} .{ }^{18}$ The informal firm profit function takes the following form:

$$
\pi_{i}^{I}=\max _{l_{i}} \theta_{i} l_{i}^{\alpha}-\left(1+\tau_{i}^{I}\right) r^{I}\left(l_{i}\right) w l_{i}-c_{I}
$$

where

$$
r^{I}\left(l_{i}\right)=\left(1+\frac{l_{i}}{b^{I}}\right)
$$

Formal firms also face 'regulatory' distortions $r^{F}\left(l_{i}\right)$, idiosyncratic distortions $\tau_{i}^{F}$ and overhead $\operatorname{costs} c^{F} .{ }^{19}$ When hiring informal workers, they face a

\footnotetext{
${ }^{16}$ We could introduce multiple skill levels into the model, following Ulyssea (2018), but the mechanisms we emphasize here would not change.

${ }^{17}$ These wedges could be due to markups, transport costs, financial frictions, corruption, or a myriad of other idiosyncratic factors introducing dispersion in marginal revenue products.

${ }^{18}$ These scale with the real wage: $c^{I}=w \gamma^{I}$.

${ }^{19}$ These also scale with the real wage: $c^{F}=w \gamma^{F}$.
} 
regulatory distortion which increases in the number of informal workers. When hiring formal workers, this regulatory distortion takes the form of a constant wedge $\tau_{w}$. This wedge is motivated by the fact that formal firms have to pay taxes and social security contributions for formal workers while informal workers obtain benefits from non-contributory government programs. The formal firm profit function takes the following form:

$$
\pi_{i}^{F}=\max _{l_{i}} \theta_{i} l_{i}^{\alpha}-\left(1+\tau_{i}^{F}\right) r^{F}\left(l_{i}\right) w l_{i}-c_{F}
$$

where

$$
r^{F}\left(l_{i}\right)= \begin{cases}\left(1+\frac{l_{i}}{b^{F}}\right) & \text { if } l_{i}<\tilde{l} \\ \frac{\tilde{l}}{l_{i}}\left(1+\frac{\tilde{l}}{b^{F}}\right)+\left(1+\tau^{w}\right) \frac{\left(l_{i}-\tilde{l}\right)}{l_{i}} & \text { if } l_{i} \geq \tilde{l}\end{cases}
$$

social security contr

Similarly to Ulyssea (2018), we obtain that there is a unique threshold $\tilde{l}$ above which formal firms exclusively hire formal workers. ${ }^{20}$ The share of informal workers in formal firms is therefore increasing in firm size.

Firms in each sector face a constant probability of exit each period: $\delta^{I}$ and $\delta^{F}$. In the steady state equilibrium, aggregate prices remain constant and the firm value function is given by:

$$
V^{S}\left(\theta_{i}, \tau_{i}^{S}\right)=\max \left\{0, \frac{\pi^{S}\left(\theta_{i}, \tau_{i}^{S}, w\right)}{\delta^{S}}\right\} \quad, S=I, F
$$

\section{$4.2 \quad$ Entry}

There is a continuum of entrepreneurs of of mass $M$ every period. Entrepreneurs do not know their productivity $\theta_{i}$ or their idiosyncratic distortions $\tau_{i}^{I}$ and $\tau_{i}^{F}$

${ }^{20}$ This threshold is given by $\tilde{l}=\frac{\tau^{w}}{2} b_{F}$. 
before making the entry decision. They do however observe a noisy signal $\nu_{i}$ of their productivity before entry, though they do not get a signal of their idiosyncratic distortions. After observing the signal, the entrepreneur chooses among the following options: i) enter the informal sector after paying an entry $\operatorname{cost} E^{I}$, ii) enter the formal sector after paying an entry cost $E^{F}$, and iii) not enter either sector. ${ }^{21}$ After entry, the entrepreneur observes $\epsilon_{i}$ and $\tau_{i}^{I}\left(\tau_{i}^{F}\right)$ and exits if $\pi_{i}^{I}<0\left(\pi_{i}^{F}<0\right)$. If $\pi_{i}^{I} \geq 0\left(\pi_{i}^{F} \geq 0\right)$ the entrepreneur starts production and becomes an incumbent firm as described in the previous subsection. Importantly, the decision to be informal/formal is taken upon entry and fixed forever from that point on. When making the entry decision the entrepreneur knows the true distributions of $\nu_{i}, \tau_{i}^{I}$ and $\tau_{i}^{F}$. The entrepreneur's pre-entry value function is therefore given by:

$$
V^{0}(\nu, w)=E\left[V^{S}\left(\theta, \tau^{S}, w\right) \mid \nu\right], S=I, F
$$

In addition, we make the following parametric assumptions about the distributions when estimating the model:

- $\theta_{i}=\nu_{i} . \epsilon_{i}$

- $\nu_{i}$ is drawn from a Pareto distribution with scale $\nu_{0}$ and shape $\xi$

- $\epsilon_{i}$ is log-normally distributed: $\ln \left(\epsilon_{i}\right) \sim N\left(0, \sigma^{2}\right)$

- $\ln \left(1+\tau_{i}^{I}\right) \sim N\left(0, \sigma_{I}^{2}\right)$ and $\ln \left(1+\tau_{i}^{F}\right) \sim N\left(\ln \left(1+\bar{\tau}^{F}\right), \sigma_{F}^{2}\right)$

\subsection{Equilibrium}

To close the model we make some simple demand-side assumptions. There is a representative household who gains utility $U(C)=C$ from consuming the homogeneous good, cannot save and inelastically supplies labor $\bar{L}$. We focus on

${ }^{21}$ Entry costs are in units of output. 
the stationary equilibrium, where aggregate prices and all distributions remain constant. We assume that revenues from all the distortions get rebated to the representative household. Total consumption is therefore given by $w L+\Pi+T$, where $w L$ is aggregate labor income, $\Pi$ is aggregate profits minus entry costs and $T$ is aggregate revenues from all distortions. The difference between aggregate output $Y$ and aggregate consumption $C$ is therefore simply given by aggregate entry costs and overhead costs. Because the distributions remain constant, we must also have that the mass of entrants in each sector is equal to the mass of incumbents times the exit rate. A stationary equilibrium is therefore defined by the following conditions:

- Labor markets clear: $L^{I}+L^{F}=\bar{L}$

- Firms maximize expected profits subject to their budget constraints

- The free entry condition holds in both sectors

- The size of each sector remains constant

\subsection{Aggregate Productivity and Misallocation}

Aggregate consumption is very sensitive to the assumption that revenues from distortions get rebated to the household. It is not clear to what extent these distortions are wasted or should get rebated. In our counterfactuals we therefore restrict ourselves to analyzing aggregate production $Y$ and we define ag-

gregate productivity as $T F P \equiv \frac{Y}{L}$. Because we explicitly incorporate idiosyncratic distortions, our model is also well equipped to discuss misallocation of inputs across firms, following Hsieh and Klenow (2009). Dispersion in distortions generate dispersion in marginal products, which lower aggregate TFP. Hsieh and Klenow (2009) infer the dispersion in distortions from dis- 
persion in revenue productivity $(T F P R) .{ }^{22}$ Marginal revenue productivity is given by simple expressions in our model. For informal firms we have that $M R P_{i}^{I}=\frac{y_{i}}{l_{i}}=\frac{1}{\alpha}\left(1+\tau_{i}^{I}\right)\left(1+2 \frac{l_{i}}{b^{I}}\right) w$. Dispersion in revenue productivity therefore comes both from dispersion in the idiosyncratic distortions and from the regulatory distortion. The regulatory distortion additionally creates a positive correlation between marginal products and productivity. For formal firms we have that $M R P_{i}^{F}=\frac{1}{\alpha}\left(1+\tau_{i}^{F}\right)\left(1+2 \frac{l_{i}}{b^{F}}\right) w$ for firms that hire only informal workers $\left(l_{i}<\tilde{l}\right)$, and $M R P_{i}^{F}=\frac{1}{\alpha}\left(1+\tau_{i}^{F}\right)\left(1+\tau_{w}\right) w$ for firms that hire formal workers $\left(l_{i}>\tilde{l}\right)$.

\section{Estimation}

In this section, we lay out how we parameterize and estimate the model described in the previous section. We calibrate some model parameters and estimate the remaining parameters using a simulated method of moments (SMM) approach. We target informative moments from the 2013 Mexican Census of Manufactures. We now describe each of the estimation steps in detail.

\subsection{Moments and identification}

In the first step of estimating the model, we calibrate the following parameters: the regulatory wedge $\tau_{w}$, the exit rate of formal firms $\delta^{F}$, the scale parameter of the productivity signal distribution $\nu_{0}$ and the parameter governing the size of overhead costs for formal firms $\gamma^{F}$. $\tau_{w}$ is set equal to .348. Using the approach from Levy (2018), this is calculated as the sum of the estimated net tax from contributory programs (.12), net payroll tax on salaried employment from (.01), benefits from non-contributory programs (.162) and the net tax from

\footnotetext{
${ }^{22}$ An extensive literature has developed documenting various sources of $T F P R$ dispersion that may not be considered 'distortions' or could be difficult to fix through standard policy tools. These include measurement error, adjustment cost and variable markups.
} 
evasion of income taxes (.056). $\delta^{F}$ is chosen to match the exit rate of formal firms in the Mexican Census data between 2008 and 2013. $\gamma^{F}$ is chosen such that overhead costs for formal firms are equal to half the monthly wage. $\nu_{0}$ is set so that the size of a firm in the informal sector with no distortion and $\theta=\nu_{0}$ is equal to 1 . There are 12 parameters to estimate in the second step: $\left\{b^{F}, b^{I}, \delta^{I}, \gamma^{I}, \xi, E^{F}, E^{I}, \alpha, \sigma, \bar{\tau}^{F}, \sigma_{I}, \sigma_{F}\right\}$. We use a SMM approach to estimate these parameters, following the approach described in detailed in Ulyssea (2018). Given a value of the wage rate $w$ these parameters are sufficient to completely describe firm behavior and constructs aggregates and model moments. We then choose 16 data moments from the Mexican Census data to target that are informative on the extensive and intensive margins of informality and the extent of misallocation in each sector. We minimize the sum of the squared deviations of the model moments from the following targeted data moments

- the share of informal workers out of all workers

- the share of formal firms out of: all firms, firms with less than 5 workers, firms with 6-10 workers, firms with 11-50 workers (extensive margin of informality)

- the share of workers that informal within formal firms with 1-5 workers

- the share of informal firms with less than 5 workers and with less than 10 workers (size distribution of informal firms)

- the share of formal firms with: less than 5 workers, 6-10 workers, 11-20 workers, 21 to 50 workers, more than 50 workers (size distribution of formal firms)

- the difference in median value-added per worker between formal firms and informal firms (informality productivity gaps) 
- the 90-10 ratio of value-added per worker for formal firms and for informal firms (TFPR dispersion)

We jointly estimate all parameters, but we provide some intuition for how different parameters are identified from our targeted moments. The average distortion in the formal sector $\left(\bar{\tau}^{F}\right)$ is identified from the value-added per worker gap between formal and informal firms. The variance of the post-entry distortion shocks $\left(\sigma^{F}\right.$ and $\left.\sigma^{I}\right)$ are critically important for determining the dispersion in value-added per worker within the informal and formal sectors. As pointed out in Section 4, dispersion in value-added per worker is also driven by the parameters governing the cost of informality $\left(b^{I}\right.$ and $\left.b^{F}\right)$, but these do not generate anywhere near enough dispersion to match the data moments. The shape parameter of the Pareto distribution $(\xi)$, the variances of the post-entry productivity shocks $(\sigma)$ and the parameter governing decreasing returns to scale $(\alpha)$ are determined by the firm size distributions. The variance of the post-entry shocks also determines the extent of overlap between the informal and formal firm size distribution. Because we have a substantial amount of dispersion in the post-entry shocks, we estimate quite a strong degree of decreasing returns to scale in order to keep the size distributions in the informal and formal sectors from overlapping too much. The entry costs in the formal sector $\left(E^{F}\right)$ affect the left tail of the size distribution of formal firms. We estimate these entry costs to be quite high for formal firms because of the relatively low share of formal firms with fewer than five workers. The relative entry costs in the two sectors is determined by the relative share of informal and formal firms. Conditional on entry costs, the exit rate of informal firms $\left(\delta^{I}\right)$ governs the overall disadvantage of entering the informal sector relative to the formal sector. The overhead costs in the informal sector $\left(\delta^{I}\right)$ impact the likelihood of post-entry survival, and are therefore directly linked to the size of the left tail of the informal sector size 
distribution. Because $b^{I}$ directly governs how the costs of informality increase with firm size, this parameter is determined by how the share of informal firms decreases with firm size. On the other hand, $b^{F}$ is most important in determining how the share of informal workers within formal firms varies with firm size.

\subsection{Parameter estimates \& model fit}

Because our model is underidentified we do not exactly match all of the targeted moments exactly. The model parameters are shown in Table 5, while the targeted data moments and model moments are presented in Table 6. Our model does a good job of matching most of the targeted moments, in particular those related to the size distribution of firms in both the formal and informal sectors. However, our model does understate the dispersion of productivity within the formal and informal sectors. This is in spite of large variation in idiosyncratic distortions in both sectors in addition to the misallocation induced by labor distortions $\tau_{w}$. In fact, labor distortions account for a small share of overall misallocation, and most of the variation obtained stems from idiosyncratic distortions that can take the form of subsidies or taxes. The gains from getting large subsidies in the informal sector are mitigated by the regulatory costs of informality $b^{I}$, and this limits our ability to get enough productivity firms in the informal sector to hit the large productivity dispersion targets. In the data, it is likely that some of this dispersion stems not only from permanent distortions but also from transitory factors and mismeasurement ${ }^{23}$ which are not captured by the model.

\footnotetext{
${ }^{23}$ Bils, Klenow, and Ruane (2019) show evidence that a significant share of reported misallocation in the U.S. and India can be attributed to mismeasurement.
} 
Table 5: Parameters

\begin{tabular}{|c|c|c|}
\hline Parameter & Description & Value \\
\hline \multicolumn{3}{|c|}{ Calibrated Parameters } \\
\hline$\tau_{w}$ & Regulatory tax wedge in formal sector & 0.35 \\
\hline$\delta^{F}$ & Exit rate in formal sector & 0.08 \\
\hline$\nu_{0}$ & Location parameter of Pareto distribution & 1,188 \\
\hline$\gamma^{F}$ & Overhead costs in the formal sector & 0.45 \\
\hline \multicolumn{3}{|c|}{ Estimated Parameters } \\
\hline$b^{F}$ & Cost parameter of informal workers for formal firms & 2.35 \\
\hline$b^{I}$ & Cost parameter of informal workers for informal firms & 4.58 \\
\hline$\delta^{I}$ & Exit rate for informal firms & 0.27 \\
\hline$\gamma^{I}$ & Overhead costs in informal sector & 0.19 \\
\hline$\xi$ & Shape parameter of Pareto distribution & 1.57 \\
\hline$E^{F}$ & Entry costs in formal sector & 93,193 \\
\hline$E^{I}$ & Entry costs in informal sector & 8 \\
\hline$\alpha$ & Decreasing returns to scale & 0.32 \\
\hline$\sigma$ & Post-entry productivity shock variance & 0.27 \\
\hline $\bar{\tau}^{F}$ & Average distortion in formal sector & 1.01 \\
\hline$\sigma_{I}$ & Post-entry distortion shock in informal sector & 1.30 \\
\hline$\sigma_{F}$ & Post-entry distortion shock in formal sector & 0.99 \\
\hline
\end{tabular}


Table 6: Model FiT

\begin{tabular}{|c|c|c|}
\hline & Data & Model \\
\hline Share of informal workers out of total workers & $56.5 \%$ & $55.4 \%$ \\
\hline Share of firms that are informal & $89.0 \%$ & $92.8 \%$ \\
\hline \multicolumn{3}{|l|}{ Extensive informality margin (share of firms) } \\
\hline Informal firms with $\leq 5$ workers & $94.0 \%$ & $95.8 \%$ \\
\hline Informal firms with $\overline{6}$ - 10 workers & $57.0 \%$ & $83.0 \%$ \\
\hline Informal firms with 11-50 workers & $35.0 \%$ & $47.9 \%$ \\
\hline \multicolumn{3}{|l|}{ Intensive informality margin (share of workers) } \\
\hline Informal workers within formal firms of size $1-5$ & $21.0 \%$ & $23.3 \%$ \\
\hline \multicolumn{3}{|l|}{ Size distribution of informal firms (share of informal) } \\
\hline Informal firms with $\leq 2$ workers & $79.0 \%$ & $76.3 \%$ \\
\hline Informal firms with $\leq 5$ workers & $96.0 \%$ & $92.7 \%$ \\
\hline \multicolumn{3}{|l|}{ Size distribution of formal firms (share of formal) } \\
\hline Formal firms with $\leq 5$ workers & $52.0 \%$ & $52.0 \%$ \\
\hline Formal firms with $6-10$ workers & $21.0 \%$ & $17.9 \%$ \\
\hline Formal firms with 11-20 workers & $13.0 \%$ & $13.5 \%$ \\
\hline Formal firms with $21-50$ workers & $8.0 \%$ & $10.1 \%$ \\
\hline Formal firms with $>50$ workers & $6.0 \%$ & $6.5 \%$ \\
\hline \multicolumn{3}{|l|}{ Productivity distribution } \\
\hline Median value-added per worker in formal vs informal & 1.05 & 0.99 \\
\hline 90-10 ratio of value-added per worker within informal & 3.49 & 2.36 \\
\hline 90-10 ratio of value-added per worker within formal & 2.64 & 2.11 \\
\hline
\end{tabular}




\section{$6 \quad$ Policy experiments and counterfactuals}

With our estimated parameters and calibrated model, we can now conduct a number of policy experiments and counterfactuals. First, we consider the gains from removing completely the net tax on formal firms coming from contributory programs. This is simulated by a reduction in $\tau_{w}$ from 35 to 23 percent. ${ }^{24}$ Second, we go further and completely remove the formal sector regulatory wedge, setting $\tau_{w}=0$. As discussed previously, we calibrated the formal sector regulatory wedge so as to capture the effects of contributory programs, taxes on salaried workers, the implicit wedge from non-contributory programs and the net tax from evasion of income taxes. In our third counterfactual, we consider a reduction in entry costs into the formal sector, first partially and then fully by equalizing them to informal sector entry costs. These sunk entry costs are motivated not only by initial investments in the firm, but also by the regulatory costs associated with starting a new formal firm. In our final counterfactual, we evaluate the gains from reducing the standard deviation of informal sector distortions to that of the formal sector. Of particular interest to us in these counterfactuals are aggregate TFP (this is proportionate to aggregate output), informal shares (of output, employment and firms), and dispersion in valueadded per worker (a measure of misallocation). These results are presented in Table 7, while in Table 8 we present how the full set of moments targeted in the estimation change in each of our counterfactuals. Figure 7 shows the distributional effects of each policy experiment for each of three firm types: firms that are formal ex-ante and ex-post, firms that are informal ex-ante and ex-post, and firms that formalize as a result of the policy experiment.

Reducing the cost of formal contracts

\footnotetext{
${ }^{24}$ Following the estimated incentive gap between formal and informal contracts estimated by Levy (2018).
} 
We find that reducing the formal sector regulatory wedge has substantial impacts on the informal share of employment and output. Removing the wedge entirely would lead to a decrease in the informal employment share from 55 to 44 percent, while the share of informal output would fall from 37 to 32 percent and fiscal revenues (interpreting the labor wedge as a tax) would moderately increase from 16 to 20 percent. Note that in this counterfactual, formal firms would not hire any informal workers - the intensive margin of informality would disappear. Despite this significant decrease in informal employment and output, we find that there would be a comparatively small increase in aggregate productivity of 2 percent. A more moderate reduction in the labor wedge, such as only eliminating the contributory social security system, would lead to similar but smaller gains. The reason for this is that reducing this labor wedge does not lead to systematic reductions in misallocation, as captured by dispersion in value-added per worker -the reduction in the wedge leads to large changes in contracting decisions, but it does not lead to a large systematic reallocation of inputs from less productive to more productive firms. Looking at the distributional effects, Figure 7 shows that reducing the cost of salaried formal contracts would benefit larger formal firms the most, at the expense of small informal firms who would face increased competition from their formal peers.

\section{Reducing entry costs by $2 / 3$}

We now consider a reduction by two thirds in formal sector entry costs. We find a significant impact on aggregate productivity of 8 percent, with a significant reduction in the number of informal firms from 93 to 77 percent and a smaller but significant impact on the informal employment share of 10 percentage points. By primarily affecting the extensive margin of informality, lowering entry costs induces the formalization of firms into the least misallocated sector and boosts the formal share of output from 80 to 97 percent and correspondingly 
the overall tax base. This contrasts the effects from the reduction in the labor wedge previously presented, which acted primarily on the intensive margin and therefore had more limited effects on misallocation and aggregate productivity.

Eliminating formalization costs

In a more extreme scenario, where formalization entry costs are eliminated, these effects are amplified. We simulate this by setting the formal entry cost parameter to that of the informal sector. All formal firms choose to be formal in this scenario. We find a significant impact on aggregate productivity of 29 percent, with a reduction in the informal employment share of 36 percentage points to reach a level of 19 percent. The resilience of informal employment follows because formal firms still hire a large number of informal workers.

Focusing on firm-specific effects, a reduction in formal sector entry costs is most beneficial to small formal firms. This is because entry costs in the baseline comprised a larger share of total costs for these small firms. Therefore, these are the firms that stand to gain the most from the entry cost reduction. The large share of informal firms who formalize after the policy change also experience large gains, while informal unproductive firms left behind lose from the increased competition.

\section{Reducing dispersion in informal sector wedges}

In our final counterfactual, we consider a reduction in the dispersion of wedges $\sigma_{I}$ in the informal sector to the level observed in the formal sector. ${ }^{25}$ We find that this would lead to significant formalization effects along the intensive margin, with the informal employment being reduced from 47 percent. Formalization effects along the extensive margin is much smaller as firms find the informal sector more attractive after distortions are reduced. Although the effects on informality are similar to those of eliminating $\tau_{w}$, the reduction of mis-

\footnotetext{
${ }^{25}$ Note that we only reduce dispersion in distortions, but we do not change the average distortion in the informal sector.
} 
allocation in the informal sector leads to larger gains of 4 percent in aggregate productivity. Gains are widespread among formal and informal firms.

Figure 7: Micro EFFECTS FROM POLICY EXPERIMENTS

Panel A. No labor distortions

Always formal

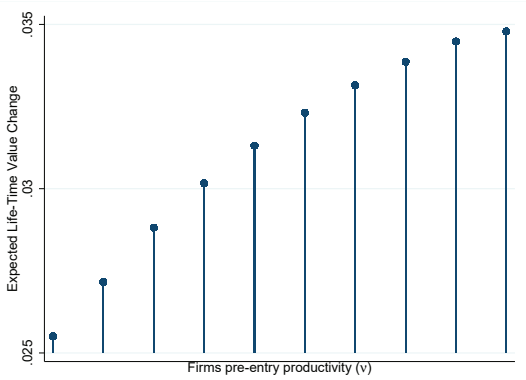

Panel C. No labor distortions Always informal

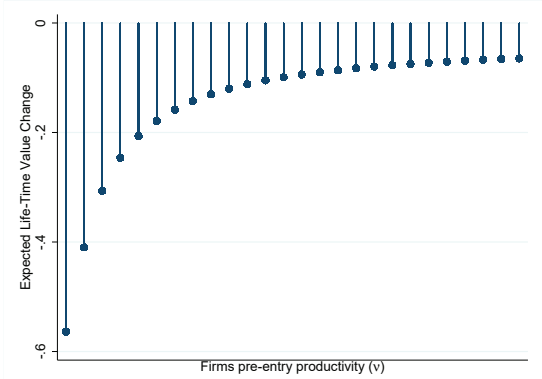

Panel E. No labor distortions Switchers

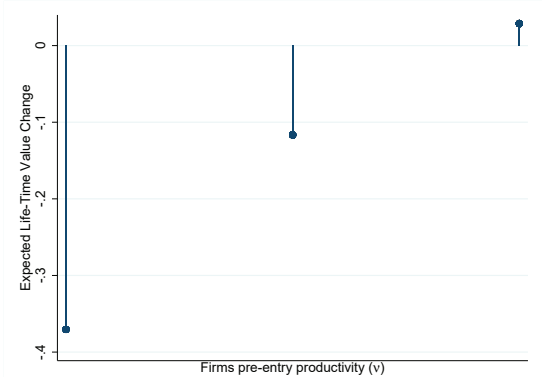

Panel B. No entry costs

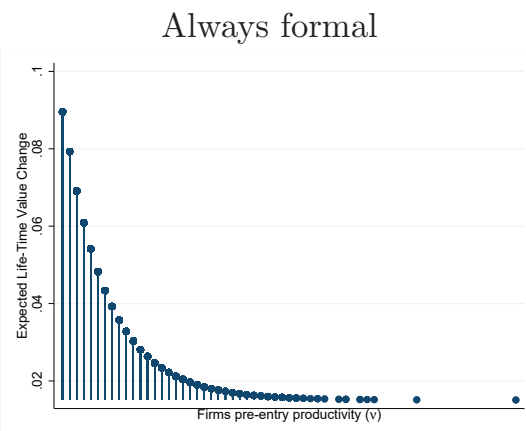

Panel D. No entry costs Always informal

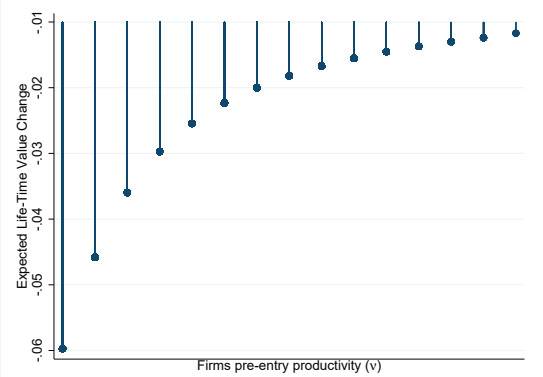

Panel F. No entry costs Switchers

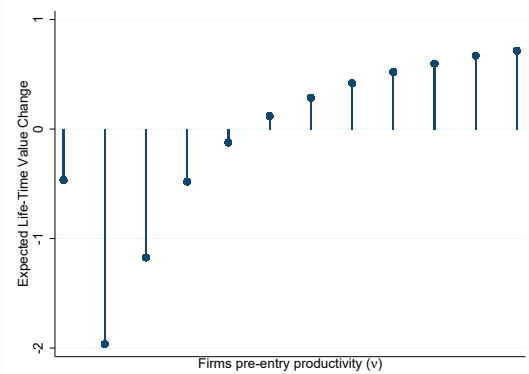

35 


\section{Conclusion}

As in other developing economies, Mexican firms operate in an environment where regulatory requirements interact with idiosyncratic distortions as well as firm and worker characteristics to produce large informal markets. The large share of informal firms across firm-size categories and economic sectors, as well as the large share of employees who are employed in informal contractual relationships at formal firms, indicate that both the intensive and extensive margins of informality are quantitatively significant in Mexico.

The link between informality and aggregate productivity is ambiguous however, as policy distortions can result in significant informal employment without necessarily generating sizeable losses in aggregate output. The key challenge is identifying the most salient distortions inducing informality and how they misallocate resources across production units. In the case of Mexico, reducing the level of labor costs induced by payroll taxes and contributory social security systems could lead to large growth in formal employment while only having moderate effects on aggregate productivity. We find that reducing entry costs into the formal sector might lead to larger aggregate productivity gains by affecting the extensive margin of informality and increasing the volume of formal firms.

The labor regulations and explicit and implicit taxes discussed in this paper fail to explain a large share of total revenue production in the Mexican Census data. To the extent that this dispersion reflect resource misallocation, other factors must be generating it. In our framework, most misallocation is attributed to idiosyncratic distortions (some of which could reflect heterogeneous enforcement of labor regulations), whose exact nature and causes are left unidentified. Future work should continue the search for the quantitatively most important distortions depressing aggregate productivity in Mexico and the corresponding 
policies to address them. In addition to reducing formalization costs, authorities should also focus on structural shortcomings preventing the development of lager productive firms regardless of their formality status. 
Table 7: Aggregate efFeCts From POLICY EXPERIMENTS

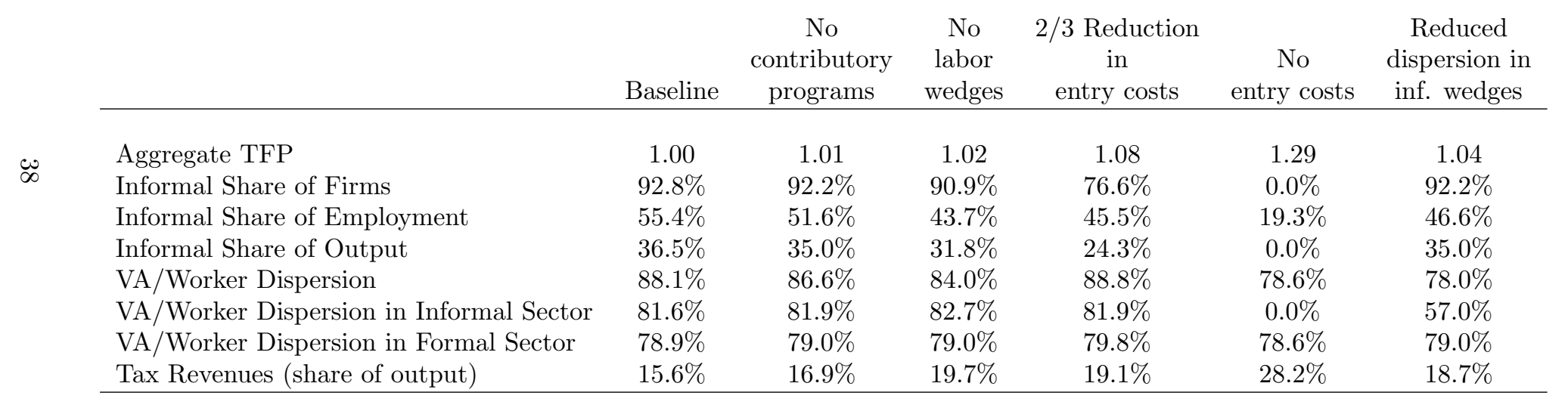


Table 8: MOdel MOMEnTS UnDER COUNTERFACTUAL SCENARIOS

\begin{tabular}{|c|c|c|c|c|c|c|}
\hline & Baseline & $\begin{array}{c}\text { No } \\
\text { contributory } \\
\text { programs }\end{array}$ & $\begin{array}{c}\text { No } \\
\text { labor } \\
\text { wedges }\end{array}$ & $\begin{array}{c}2 / 3 \text { Reduction } \\
\text { in } \\
\text { entry costs }\end{array}$ & $\begin{array}{l}\text { No } \\
\text { entry costs }\end{array}$ & $\begin{array}{c}\text { Reduced } \\
\text { dispersion in } \\
\text { inf. wedges }\end{array}$ \\
\hline Share of informal workers & $55.4 \%$ & $51.6 \%$ & $43.7 \%$ & $45.5 \%$ & $19.3 \%$ & $46.6 \%$ \\
\hline Share of firms that are informal & $92.8 \%$ & $92.2 \%$ & $90.9 \%$ & $76.6 \%$ & $0.0 \%$ & $92.2 \%$ \\
\hline \multicolumn{7}{|l|}{ Extensive informality margin (share of firms) } \\
\hline Informal firms with $\leq 5$ workers & $95.8 \%$ & $95.6 \%$ & $94.9 \%$ & $79.6 \%$ & $0.0 \%$ & $95.8 \%$ \\
\hline Informal firms with $\overline{6}-10$ workers & $83.0 \%$ & $81.2 \%$ & $76.8 \%$ & $63.9 \%$ & $0.0 \%$ & $71.3 \%$ \\
\hline Informal firms with 11-50 workers & $47.9 \%$ & $43.8 \%$ & $34.9 \%$ & $27.7 \%$ & $0.0 \%$ & $10.4 \%$ \\
\hline \multicolumn{7}{|l|}{ Intensive informality margin (share of workers) } \\
\hline Informal workers within formal firms of size $1-5$ & $23.3 \%$ & $15.3 \%$ & $0.0 \%$ & $30.0 \%$ & $39.7 \%$ & $22.9 \%$ \\
\hline \multicolumn{7}{|l|}{ Size distribution of informal firms (share of informal) } \\
\hline Informal firms with $\leq 2$ workers & $76.3 \%$ & $77.1 \%$ & $79.2 \%$ & $79.4 \%$ & $0.0 \%$ & $81.9 \%$ \\
\hline Informal firms with $\leq 5$ workers & $92.7 \%$ & $93.0 \%$ & $94.0 \%$ & $94.3 \%$ & $0.0 \%$ & $97.2 \%$ \\
\hline \multicolumn{7}{|l|}{ Size distribution of formal firms (share of formal) } \\
\hline Formal firms with $\leq 5$ workers & $52.0 \%$ & $50.8 \%$ & $50.7 \%$ & $79.1 \%$ & $96.8 \%$ & $50.1 \%$ \\
\hline Formal firms with 6 -10 workers & $17.9 \%$ & $18.4 \%$ & $17.5 \%$ & $9.8 \%$ & $1.7 \%$ & $17.6 \%$ \\
\hline Formal firms with 11-20 workers & $13.5 \%$ & $13.8 \%$ & $13.6 \%$ & $5.6 \%$ & $0.8 \%$ & $14.1 \%$ \\
\hline Formal firms with 21-50 workers & $10.1 \%$ & $10.1 \%$ & $10.7 \%$ & $3.7 \%$ & $0.4 \%$ & $10.6 \%$ \\
\hline Formal firms with $>50$ workers & $6.5 \%$ & $6.9 \%$ & $7.6 \%$ & $1.8 \%$ & $0.2 \%$ & $7.5 \%$ \\
\hline \multicolumn{7}{|l|}{ Productivity distribution } \\
\hline Median value-added per worker in formal vs informal & 0.99 & 0.93 & 0.73 & 1.07 & 0.00 & 1.02 \\
\hline 90-10 ratio of value-added per worker within informal & 2.36 & 2.37 & 2.41 & 2.38 & 0.00 & 1.55 \\
\hline 90-10 ratio of value-added per worker within formal & 2.11 & 2.12 & 2.10 & 2.06 & 1.89 & 2.10 \\
\hline
\end{tabular}




\section{References}

Almeida, Rita, and Pedro Carneiro. 2012. "Enforcement of labor regulation and informality." American Economic Journal: Applied Economics, 4(3): 6489.

Antón, Arturo, Fausto Hernández, and Santiago Levy Algazi. 2013. "The end of informality in México?: fiscal reform for universal social insurance."

Bertrand, Marianne, C Hsieh, and Nick Tsivanidis. 2015. "Contract labor and firm growth in india."

Bils, Mark, Peter J Klenow, and Cian Ruane. 2019. "Misallocation or Mismeasurement?"

Bosch, Mariano, M Belén Cobacho, and Carmen Pages. 2014. "Effects of non-contributory systems on informality: Taking stock of eight years of implementation of Mexico's Seguro Popular." M. Frölich; D. Kaplan; C. Pages; D. Robalino, 80-111.

Bruhn, Miriam. 2011. "License to Sell: The Effect of Business Registration Reform on Entrepreneurial Activiy in Mexico." The Review of Economics and Statistics, 93(1): 382-386.

Bruhn, Miriam. 2013. "A tale of two species: Revisiting the effect of registration reform on informal business owners in Mexico." Journal of Development Economics, 103: 275-283.

Charlot, Olivier, Franck Malherbet, and Cristina Terra. 2015. "Informality in developing economies: Regulation and fiscal policies." Journal of Economic Dynamics and Control, 51: 1-27.

40 
De Andrade, Gustavo Henrique, Miriam Bruhn, and David McKenzie. 2013. A helping hand or the long arm of the law? Experimental evidence on what governments can do to formalize firms. The World Bank.

D'Erasmo, Pablo N, and Hernan J Moscoso Boedo. 2012. "Financial structure, informality and development." Journal of Monetary Economics, 59(3): 286-302.

DeSoto, Hernando, et al. 1989. "The Other Path."

Dix-Carneiro, Rafael, Pinelopi Koujianou Goldberg, Costas Meghir, and Gabriel Ulyssea. 2018. "Trade and informality in the presence of labor market frictions and regulations."

Doing Business. 2019a.

Fajnzylber, Pablo, William F Maloney, and Gabriel V MontesRojas. 2011. "Does formality improve micro-firm performance? Evidence from the Brazilian SIMPLES program." Journal of Development Economics, 94(2): 262-276.

Heckman, James J, and Carmen Pagés. 2004. "Law and Employment: Lessons from Latin America and the Caribbean-An Introduction." Law and employment: lessons from Latin America and the Caribbean.

Hsieh, Chang-Tai, and Peter J Klenow. 2009. "Misallocation and manufacturing TFP in China and India." The Quarterly journal of economics, 124(4): 1403-1448.

Hsieh, Chang-Tai, and Peter J Klenow. 2014. "The life cycle of plants in India and Mexico." The Quarterly Journal of Economics, 129(3): 1035-1084.

INEGI. Mexican Economic Census. 2013. 
INEGI. National Employment and Occupation Survey. $2019 b$.

Kaplan, David, Eduardo Piedra, and Enrique Seira. 2011. "Entry regulation and business start-ups: Evidence from Mexico." Journal of Public Economics, 95(11-12): 1501-1515.

La Porta, Rafael, and Andrei Shleifer. 2014. "Informality and development." Journal of Economic Perspectives, 28(3): 109-26.

Leal, Julio Cesar. 2014. "Tax collection, the informal sector, and productivity." Review of Economic Dynamics, 17(2): 262-286.

Levy, Santiago. 2018. Under-rewarded efforts: The elusive quest for prosperity in Mexico. Inter-American Development Bank.

Meghir, Costas, Renata Narita, and Jean-Marc Robin. 2015. "Wages and informality in developing countries." American Economic Review, 105(4): 1509-46.

Monteiro, Joana CM, and Juliano J Assunção. 2012. "Coming out of the shadows? Estimating the impact of bureaucracy simplification and tax cut on formality in Brazilian microenterprises." Journal of Development Economics, 99(1): 105-115.

Rocha, Rudi, Gabriel Ulyssea, and Laísa Rachter. 2018. "Do lower taxes reduce informality? Evidence from Brazil." Journal of Development Economics, 134: 28-49.

Ulyssea, Gabriel. 2018. "Firms, informality, and development: Theory and evidence from Brazil." American Economic Review, 108(8): 2015-47.

Ulyssea, Gabriel, and Vladimir P Ponczek. 2018. "Enforcement of Labor Regulation and the Labor Market Effects of Trade: Evidence from Brazil." 